\title{
Tomaž Toporišič
}

\section{Myth and Creolisation of Cultures and Performing Arts in the Mediterranean*}

Keywords: Creolisation, performing arts, Mediterranean, otherness

DOI: $10.4312 /$ ars.9.1.104-116

\section{1 "Le Roi est mort, vive le Roi!"}

Theatre today manifests a new type of cultural manifoldness. It is characterized by a creolisation or intermingling of two or several formerly discrete traditions or cultures: one can interpret it as a series of transcultural identity networks, woven from different threads and deriving from myths shared by the entire territories, Mediterranean basin being one of the most interesting examples and fields for this kind of research.

I will begin the discussion about myth and creolisation of cultures and performing arts in the Mediterranean basin to which belongs also Slovenia with a paraphrasing of the famous statement "Le Roi est mort, vive le Roi!" - the declaration traditionally made by the Duc d'Uzès, a senior Peer of France, as soon as the coffin containing the remains of the previous king descended into the vault of Saint Denis Basilica. This is being used to describe a paradox connected to the phenomena of modernism and postmodernism. If we all proclaim that the postmodern condition has been abandoned, we appear much less in accord as to what to make of the state it has been abandoned for. As if we were not able to find the body in the coffin or to locate the successor to which we would transfer the sovereignty. Le mort saisit le vif simply does not work. We have no immediate transferral of power behind the phrase.

In order to illustrate this situation I will quote two statements about the death of postmodernism pronounced by two contemporary theorists of art and culture, Mikhail Epstein and Nicolas Bourriaud.

1. In a 1999 book, Russian Postmodernism. New Perspectives on Post-Soviet Culture, the Russian-American scholar Mikhail Epstein decides to designate the new era following "postmodernism" with the prefix "trans-":

The last third of the $20^{\text {th }}$ century developed under the sign of "post", which signalled the demise of such concepts of modernity as "truth" and "objectivity",

The Slovene version of this article is available on: http://revije.ff.uni-lj.si/arshumanitas. / Slovenska različica članka je dosegljiva na http://revije.ff.uni-lj.si/arshumanitas. 
"soul" and "subjectivity", "utopia" and "ideality", "primary origin" and "originality", "sincerity" and "sentimentality". All of these concepts are now being reborn in the form of "trans-subjectivity", "trans-idealism", "transutopianism", "trans-originality", "trans-lyricism", "trans-sentimentality" etc. (Epstein, 1999).

Epstein's prefix trans- is a reference to what's happening in Russian art - and is mostly linked to the field of literature - but the idea of "trans"- gression could be borrowed to serve as a presupposition to a specific theatrical style of physicality within the field of the performing arts. The physically advanced bodies of the actors can thus tell unique stories that will extend one's imagination to limitless boundaries.

2. In his Altermodern Manifesto French theoretician and curator Nicolas Bourriaud coins a new term, one he thinks could define the new art. Instead of "trans-" he chooses “alter". In his Altermodern Manifesto, written for London's 2009 Tate Triennial exhibition, he declared: POSTMODERNISM IS DEAD.

A new modernity is emerging, reconfigured to an age of globalisation understood in its economic, political and cultural aspects: an altermodern culture

Increased communication, travel and migration are affecting the way we live Our daily lives consist of journeys in a chaotic and teeming universe

Multiculturalism and identity is being overtaken by creolisation: Artists are now starting from a globalised state of culture

This new universalism is based on translations, subtitling and generalised dubbing

Today's art explores the bonds that text and image, time and space, weave between themselves

Artists are responding to a new globalised perception. They traverse a cultural landscape saturated with signs and create new pathways between multiple formats of expression and communication. ${ }^{1}$

In the introduction to the exhibition Bourriaud wrote:

Usually an exhibition begins with a mental image with which we need to reconnect, and whose meanings constitute a basis for discussion with the artists. The research that has preceded the Triennial 2009, however, had its origins in two elements: the idea of the archipelago, and the writings of a German émigré to the UK, Winfried Georg Sebald. The archipelago (and its kindred forms, the constellation and the cluster) functions here as a model representing the multiplicity of global cultures [...] As for Sebald's writings - wanderings between 'signs', punctuated by black and white photographs -

1 http://www.tate.org.uk/britain/exhibitions/altermodern/manifesto.shtm [10. 10. 2011]. 
they appear to me as emblematic of a mutation in our perception of space and time, in which history and geography operate a cross-fertilisation, tracing out paths and weaving networks: a cultural evolution at the very heart of this exhibition. The two concepts - the archipelago and Sebald's excursions - do not intertwine arbitrarily: they represent the paths I followed led by my initial intuition: that of the death of postmodernism as the starting point for reading the present (Bourriaud, 2009).

\section{The language of art has no centre and no borders}

Nicolas Bourriaud chooses as an exemplary artist the German novelist W. G. Sebald, who, in Bourriaud's view, lays out the territory of what he calls the "Altermodern", an "other" modern - a rootless modernism for the $21^{\text {st }}$ century, a synthesis of modernism and post-colonialism, in which the artist "turns cultural nomad". With their detached emotional tone, Sebald's books take us on journeys around Europe, into the past and across the uncertain terrains of memory, history and fiction.

"There are no longer roots to sustain forms, no exact cultural base to serve as a benchmark for variations, no nucleus, no boundaries for artistic language", says Bourriaud. Sebald's writings follow a similar wandering path, as do the real and imaginary journeys of the artists in question. Bourriaud also wrote:

If twentieth-century modernism was above all a western cultural phenomenon, altermodernity arises out of planetary negotiations, discussions between agents from different cultures. Stripped of a centre, it can only be polyglot. Altermodernity is characterized by translation, unlike the modernism of the twentieth century which spoke the abstract language of the colonial west, and postmodernism, which encloses artistic phenomena in origins and identities (Bourriaud, 2009).

Let us take another example: a performance conceived and directed by an American choreographer for the Ljubljana-based Mladinsko Theatre premiered in May 2014. Un vent de folie (A Crazy Wind) is a project in which a charismatic choreographer, director, dancer and performer decided to closely collaborate for the very first time with Slovene actors. Like the Crazy Wind from the title of the performance, this artistic collaboration points in several directions. ${ }^{2}$

For those interested in the history of performing arts as well as for those that worship Josephine Baker, the very icon of the American Paris-based 1920's theatrical

2 Mark Tompkins: Un vent de folie / Veter norosti, Slovensko mladinsko gledališče, Ljubljana, 2013/2014 season. 
and musical avant-garde (in the way that Ivan $\mathrm{Mrak}^{3}$ the most peculiar Slovene "tragedist" of the $20^{\text {th }}$ century, did; he dedicated one of his hymnic tragedies to her memory), the performance suggests a specific homage to this dancer. More specifically, it alludes to the famous Banana costume she wore for her wild dance scene with a special version of the Charleston in the vaudeville Un vent de Folie in 1927.

This very costume is one of the main visual props of the "crazy" or "folle" or even better "folie" Paris in the beginning of the last century, introducing to the European artistic scene and culture a sense of a strong wind of spring. This wind of spring undoubtedly served as an inspiration for the theatrical imagination and magic of Mark Tompkins and Jean-Louis Badet during their process of shaping the spring of new artistic forms: a new art to be born out of the pagan tradition - the tradition of the Slovene kurents (wild men), a great inspiration for Tompkins and Badet. But this spring has to be linked to the spring of the crazy twenties with The Rite of Spring bringing together the music of Igor Stravinsky and Vaclav Nijinsky for Les Ballets Russes and Josephine Baker and her wildly fascinating acts on the Folies Bergères stage. It also has to be linked to something completely contemporary: the Arab Spring as a social and political phenomena, because of which we were for a limited time misled to believe that a political spring has come, ending the period of the neoliberal winter.

Among these springs one could easily find also the Slovene political spring of the last two decades of the $20^{\text {th }}$ century as well as some other Slovene springs. These Slovene springs include the one of the Liberation Front during the Second World War, the spring of the post-war socialism, the spring of the sexual and student revolutions of the 1970s, the spring of the protests and uprisings against the neoliberal politics and corruption during the last two years - that is, the springs that brought the spirit one could compare to the one brought by the Arab Spring three years ago (a spring that would bring the spirit of the egalitarian political spring also to Slovenia).

Tompkins organised his performance as a specific performative dialogue between the Slovene folk and poetical tradition on the one hand and the traditional of American and French theatrical genres such as vaudeville, minstrel show, operetta, cabaret, music hall on the other. These heterogeneous forms are bound together by a genre of the dance theatre originating in the principle of the contact improvisation.

Kurent as a wild man embodied in an erotic figure of a woman is transformed in A Crazy Wind into various icons of the $20^{\text {th }}$ century who perform in the dialogues of theatre, music and dance ranging from the anthropological armoury of folk, partisan and pop songs, fiction, the clown-like tradition of Monsieur Loyal, the tradition of American Westerns, the bizarre forms of music theatre and musicals to the famous 
grotesque Jacobean tragedy 'Tis a Pity She's a Whore by John Ford, cut in its most dramatic moments by Betty Mae Page, the queen of the pin up girls from Nashville and New York of the 1950s (from movies like Trip-o-Rama, Varietease and Teaserama), and finally the queer performance of the cowboy pop hit of Bing Crosby "I'm an Old Cow Hand (from the Rio Grande)" from 1936. And as a special highlight of the iconoclasms, the weirdest of all possible combinations: Artaud's essay Theatre and Plague performed by "Cruella" accompanied by partisan, pioneer and Heimat songs in a cappella technique.

In Un vent de folie Tompkins travels into the regions of complex iconographies, images and stories structuring the semiosphere of the performance in which borders are made to be crossed. This specific border crossing applies to all the elements of the performance: from genres creating a melting pot of streams negating the hierarchy and dichotomy of High and Popular culture. Thus they create a platform for the creolisation of cultures in which fiction, drama, poetry, vaudeville, theory, dance, music and cirque build up dialogues, trialogues and polyphonies. All this is to create a form of Artaudian liberated stage in which the logocentrism is being replaced by the visual, physical and metaphorical language of the stage.

\section{Multiculturalism has been replaced by Creolisation}

Seeberg and Tompkins are witnesses of a process in which multiculturism and identity are being overtaken by 'creolisation' in which artists start from a "global state of culture". But they are far from being lonely examples. A perfect example of creolisation as well as the altermodernist position of the artist is one of Canada's most honoured theatre artists Robert Lepage. The characters of his performances from The Dragon Trilogy to The Bluedragon have no fixed national identity; they are above it, in the air, constantly displaced, free as a bird, changing their identity according to their current needs.

Furthermore: Creolisation of cultures within the field of performing arts became even a starting point for a trans-national European University Project 'Playing Identities, Performing Heritage: Theatre, Creolisation, Creation and the Commons', a two-year interdisciplinary collaboration between the Department of Scienze Storiche e Beni Culturali at the University of Siena, Italy, the Drama Department at the University of Kent, and four Academies of Dramatic Arts in Romania, Spain, Lithuania and the UK. The project aims to investigate how theatre and performance might contribute to the production of new 'creolised' European forms of identity and heritage by promoting artistic residencies in which acting and directing students in 
the participating academies collaborate cross-culturally, and by fostering audience participation through an online platform called Pan Speech. It will culminate in a cycle of Creole Performances which will be presented at a festival in Siena in the summer of 2016.

Creolisation, as it is used by some anthropologists, is an analogy taken from linguistics. This discipline in turn took the term from a particular aspect of colonialism, namely the uprooting and displacement of large numbers of people in the plantation economies of certain colonies, such as Louisiana, Jamaica, Trinidad, La Réunion and Mauritius. The concept of cultural creolisation, introduced in anthropology by Ulf Hannerz, refers to the intermingling and mixing of two or several formerly discrete traditions or cultures. Hannerz defines creole cultures as follows:

Creole cultures - like creole languages - are intrinsically of mixed origin, the confluence of two or more widely separated historical currents which interact in what is basically a center/periphery relationship. [However, the cultural processes of creolization are not simply a matter of constant pressure from the center toward the periphery, but a much more creative interplay. [...] Creole cultures come out of multi-dimensional cultural encounters and can put things together in new ways (Hannerz, 1992, 264-265).

In an era of global mass communication and capitalism, creolisation can be identified nearly everywhere in the world, but there are important differences as to the degree of mixing. The concept has been criticized for essentialising cultures (as if the merging traditions were "pure" at the outset). Although this critique may sometimes be relevant, the concept nevertheless helps make sense of a great number of contemporary cultural processes, characterised by movement, change and fuzzy boundaries. The concept of creolisation can therefore be applied to a wide range of performative practices, from the "original" politico-aesthetic process of creolization of the Jamaican dance theatre's ongoing abstraction from African Jamaican folk ritualistic roots to a unique modern dance vocabulary (see Dancing Postcolonialism: The National Dance Theatre Company of Jamaica, p. 20) or Derek Walcott's creolization of the myth of Odysseus in his play The Odyssey (1993) to the above discussed Sebald and Tompkins and other "Western" cultural phenomena, such as Slovene poet and dramatist Veno Taufer's "creolized" version of the Odyssey, 1990 poetic play Odysseus and Son or World and Home.

At this point I would like to move our focus to the specific features of Mediterranean basin: I will allude to the well-known article Metaphors for the Mediterranean: Creolization or Polyphony? by Thierry Fabre and published in Mediterranean Historical Review (2002). 
The article explores Edouard Glissant's notion of 'creolisation' as a metaphor for the Mediterranean world. It compares the Mediterranean with the West Indies in this regard. The author is sceptical about the usage of the two terms in order to explain the Mediterranean, but nevertheless he does not give us an alternative to both usages. He thinks that creolisation, a process of adaptation to the whole world, does not help us to understand the play of identity in the contemporary Mediterranean world, for here genealogy and transcendence remain central. Therefore he examines the notion of polyphony, in which the voices come together without melding, as a possible alternative. Fabre's concept can be linked to the very notion of Bahtin's poliphony carried out not in terms of fusion but of ironisation, his dialogism that sets different elements against each other. But given the current political, cultural, and religious conflict and the constant confusion between the proper and the pure polyphony, this seems to him less an appropriate metaphor than a promise. This could lead to the conclusion that creolisation is nevertheless quite an appropriate notion that helps to explain at least some of the characteristics of the Mediterranean cultural space as well as some other specific cultural spaces. ${ }^{4}$

But these thoughts could lead us far from the theme of this essay. So let us return to Altermodernism. In Bourriaud's view contemporary artists, or at least some groups among them, see the globalised state of culture as something that is already a matter of fact: in every corner of the planet, you can see this new cultural stratus, coexisting with the layer of traditional culture and some local specific contemporary elements. Saying that it is the privilege of the artistic jet set is a pure denial of the worldwide violence of the capitalist system, or an extreme naiveté.

He thinks - and here I quote him again - "that this theoretical resistance, which consists in sticking to the multiculturalist dogma, is hiding a paternalist pattern: it jails the individuals into their so-called 'origins' and their 'identities'. Let's face it: artists now have access to information, and they all use the same toolbox, from Stockholm to Bangkok. Or shouldn't they?"5

Bourriaud thinks that we have to get out of this dialectical loop between the global and the local, to get rid of the binary opposition between globalization and traditions. "And what is the name of this third way? Modernity, whose historical ambiguity is directed against both standardization and nostalgia" (Ibid).

4 The process of a specific Mediterranean creolization could be (similar to that of Derek Walcott's specific alterations that give Caribbean meaning to The Odyssey on stage) traced and discussed in Veno Taufer's already mentioned version of the Mediterranean myth of Odyssey given specific postsocialist Slovene medning to the Odyssey on stage.

5 http://www.artinamericamagazine.com/news-opinion/conversations/2009-03-17/altermodern-aconversation-with-nicolas-bourriaud/ [13. 10. 2011]. 


\section{Theatre as a sort of cultural heterogeneity}

We might be quite certain that there is something presumptuous or at best naïve in proposing a theory of this third way, the alter-modernity that can be able to avoid the binary logic. But nevertheless, as Patrice Pavis, French theorist of performing arts states in his book Theatre at the Crossroads of Culture, all provisory answers to questions about the status of the contemporary culture, altermodernism, interculturalism, bear in themselves dangers of oversimplifications (given the complexity of the factors at stake in all cultural exchange and the difficulty of formalizing them). Every typology of cultural relations requires a metalanguage that would be, as it were, 'above' these relations, encompassing them all.

In his essay "Intercultural Theatre today (2010)" he, furthermore, points out that "the denomination 'intercultural theatre' is falling out of use. The term 'intercultural performance' would be more suitable to signal from the outset the opening to very different 'cultural performances"' (Pavis, 2010, 8-9) He sees intercultural performance as something that can be distinguished from the following genres, of which it is often a variant or a specialization: Multilingual theatre, Syncretic theatre, Postcolonial theatre, Creolized theatre, Multicultural theatre, Minority theatre, etc. Within this scope Pavis defines creolized theatre as something that "look[s] for the encounter, the difference, the relationship, of writing 'in presence of all languages of the world' (Edouard Glissant), so as to better fight the standardizing globalization. They refer above all to the language, enriched in a Tout-monde (all-world), which, however chaotic and unpredictable, is far from multiculturalism" (Pavis, 2010, 10).

It is hard to imagine where theorists would find the metalanguage Pavis speaks about, especially since they are themselves caught up in a language and culture from which it is difficult to disengage. Furthermore, there is no general theory of culture that correctly integrates historical, social and ideological factors without being reduced to them. Cultural studies have had the merit of rehabilitating phenomena that are not situated in the socioeconomic infrastructure and that cannot be described in purely economic or sociological terms. Conversely, however, they sometimes tend to dissolve all socioeconomic political and ideological factors in culture, to present the cultural as the social element in individual behaviour, foregrounding the influence of the individual unconscious on cultural phenomena. As Pavis puts it:

We must avoid two exaggerations: that of a mechanical and unreconstructed Marxism that neglects the importance of cultural phenomena and their relative autonomy, and that of a culturalism that turns the economic and ideological infrastructure into a form of unconscious discursive superstructure (Pavis, 1992, 183). 
It is not my aim to enter into a discussion of whether Bourriaud's new term represents a breakthrough in current discussions about the new era of globalization. Further, it is not my aim to discuss whether altermodernism is another theory in the line of victims that Edward Said would dub a new version of the cultural struggles between imperial and dominated societies that continue into the present.

Bourriaud seems to be avoiding the classical question of postcolonial theory, namely the concern with a range of cultural engagements: the impact of imperial languages upon colonised societies; the effects of European 'master-discourses' such as history and philosophy; the nature and consequences of colonial education and the links between Western knowledge and colonial power. In particular, it is concerned with the responses of the colonised: the struggle to control self-representation, through the appropriation of dominant languages, discourses and forms of narrative; the struggle over representations of place, history, race and ethnicity; and the struggle to present a local reality to a global audience.

What I would like to point out is the fact that with his definition of altermodernism as "the in-progress redefinition of modernity in the era of globalization, stressing the experience of wandering in time, space and medium" Bourriaud could be speaking also about the dilemmas both theorists and artists have been facing during the last decades.

To sum up: Theatre today speaks for a new type of cultural manifoldness arising, a broad range of new differences that is developing as well. Creolisation or intermingling and mixing of two or several formerly discrete traditions or cultures, transcultural identity networks, woven from partly the same and from partly different threads, aren't all of the same colour and pattern, deriving from myths that the entire Mediterranean basin shares. In this sense (in analogy to the world of music, in which the process of creolisation seems to be the strongest point in the Mediterranean basin), one could speak about a specific Mediterranean in motion that emerges also within the field of the performing arts, a specific process of "travelling cultures", of real (and today also virtual) networks. Within such an understanding of culture theatre needs to speak not only against domination but it needs also to ensure that the hard-earned insights of the field - about the importance of marginality, otherness, and local contexts - should not be foreclosed by literary-minded applications.

The decolonisation of cultural practices can be achieved if we make a consensus that "we have reached a time when no values from any single cultural perspective can provide frameworks adequate to understanding the changes affecting all of us" (Lee, 1995). The most productive motto still appears to be that we must "think global and act local". We need the broad global perspective with 
universal myths, but we must be aware of our local circumstances and the local myths upon which we usually want to act. The ensuing dialectical relation between the two will allow us to attain results in both. In my country, Slovenia, one often hears scholars complain that, excepting specialists, nobody is "internationally" interested in local myths or national topics. This is not true: what we need to find is an appropriate way of presenting local or national topics within an international and global setting.

\section{Post-gravital Post-scriptum}

I will conclude with Dragan Živadinov's small manifesto POSTGRAVITY ART, which reflects the ambiguities and controversies of the post- era. The impossibility of transgression and the fact that whenever we define post art mean that we have to use the very vocabulary of the modernism and avant-garde. I quote:

Postgravity art is defined as all art created in zero gravity conditions. In these new living conditions it will create systems that we are not yet aware of. Postgravity art is not a stylistic formation and does not intend to become that either. Millennia spent in gravity "I" have created everything, whether living or inanimate. Directly or indirectly, art too has been shaped in this way, above all its structural elements. Only $20^{\text {th }}$ century art, with its thoughts on antimimesis, conceptualisation and telelogy has opened up the field of gravity " 0 ". The $21^{\text {st }}$ century is using avant-garde methodologies of the previous century to develop ideas on postgravity art. ${ }^{6}$

What is the use of the theory and practice of the performing arts within Živadinov's utopic scheme of postgravity? One could say one of its wild cards is that it develops a myth of the zero gravity that follows the tradition of antique myths, such as that of Icarus and his aim to reach to the sky. As well as many other myths that enlightened the cartography of myths from middle ages, renaissance till today. Bourriaud could interpret this specific "gravity zero" creolisation of cultures and myths as the work of the artist responding to a new globalised perception. According to altermodernist manifesto, Živadinov's performances traverse a cultural landscape saturated with signs and create new pathways between multiple formats of expression and communication. In his projects the proto-myth of Icarus meets the performers embodying the postgravity myth, a new version of Icarus's utopic aim to reach the sky.

6 http://www.scribd.com/doc/31079708/50-Topics [13. 10. 2011]; see also: http://reformmedia. blogspot.com/2010/07/noordung-1995-2045_15.html. 


\section{References}

Bartholomew, R., Altermodern: A Conversation with Nicolas Bourriaud, Art in America, March 17, 2009.

Bourriaud, N., 'Altermodern', in Altermodern: Tate Triennial (ed. Bourriaud, N.), London 2009, http://www.scribd.com/doc/29398878/Bourriaud-Altermodern [12. 10. 2014].

Bourriaud, N., 'Altermodern Manifesto', online: Tate website: http://www.tate.org.uk/ britain/exhibitions/altermodern/manifesto.shtm.

Epstein, M. et al., Russian Postmodernism. New Perspectives on Post-Soviet Culture. New York 1999, http://www.focusing.org/apm_papers/epstein.html [12. 9. 2011].

Fabre, T., Metaphors for the Mediterranean: Creolization or Polyphony?, Mediterranean Historical Review 17 (1), 2002, pp. 15-24.

Glissant, E., Le Discours antillais, Paris 1981.

Hannerz, U., Cultural Complexity, New York and Chichester 1992.

Horden, P., Purcell, N., The Corrupting Sea: A Study of Mediterranean History, Oxford 2000.

Hutcheon, L., The Politics of Postmodernism, New York, London 2002.

Lee, B., Critical internationalism, Public Culture 7 (3), 1995, pp. 559-592.

Pavis, P., Theatre at the Crossroads of Culture. London, New York 1992.

Pavis, P., Intercultural theatre today (2010), Forum Modernes Theater, München, Band 25/1, 2010, pp. 5-15.

Sörgel, S., Dancing Postcolonialism: The National Dance Theatre Company of Jamaica, Bielefeld, Transcript, 2007.

Živadinov, D., 50 kordinat / 50 Topics, http://www.scribd.com/doc/31097592/50kordinat; http://www.scribd.com/doc/31079708/50-Topics [13. 10. 2014]. 


\section{Tomaž Toporišič}

\section{Mit in kreolizacija kultur ter uprizoritvene umetnosti v Sredozemlju}

Ključne besede: kreolizacija, uprizoritvene umetnosti, Sredozemlje, drugost

Gledališče danes priča o novi vrsti kulturne mnogovrstnosti, o širokem spektru novonastajajočih razlik. Vzporedno pa poteka proces kreolizacije, ki postaja vedno bolj značilen za sodobno kulturo in uprizarjanje ter ga lahko definiramo kot prepletanje dveh ali več prej diskretnih kulturnih tradicij - kot nekakšno prepletanje podobnih, a vendar različnih koloritov, izhajajočih iz mitov, skupnih celotnemu sredozemskemu bazenu. Znotraj takšnega razumevanja kulture mora gledališče spregovoriti ne samo proti dominaciji, ampak tudi o pomenu marginalnosti, drugačnosti in lokalnih kontekstov.

Kot zapiše Benjamin Lee, »živimo v času, ko nobena od vrednot kateregakoli posameznega kulturnega vidika ne more zagotoviti ustreznega okvirja za razumevanje sprememb, ki vplivajo na vse nas«, vključno z dekolonizacijo kulturnih praks. Razmišljati moramo globalno, delovati pa lokalno, zavedati se moramo univerzalnih mitov, hkrati pa tudi lokalnih razmer in mitov, ki nas obkrožajo. V Sloveniji se strokovnjaki pogosto pritožujejo, da se razen specialistov nihče "mednarodno ne zanima za lokalne mite in nacionalne teme. Ta teza preprosto ne zdrži: vsekakor pa je treba najti ustrezen način za predstavitev lokalnih in nacionalnih tem znotraj mednarodnega in globalnega konteksta. 


\section{Tomaž Toporišič \\ Myth and Creolisation of Cultures and Performing Arts in the Mediterranean}

Keywords: Creolisation, performing arts, Mediterranean, otherness

Theatre today speaks for a new type of cultural manifoldness, for a broad range of new differences that are developing. Creolisation is the intermingling of two or several formerly discrete traditions or cultures; it is an interweaving of similar and different threads of various colours, deriving from myths shared throughout the Mediterranean basin. Within such an understanding of culture theatre needs to speak out not only against domination but also needs to highlight the importance of marginality, otherness, and local contexts. It should not be hemmed in by literary-minded applications.

As Benjamin Lee writes, "we have reached a time when no values from any single cultural perspective can provide frameworks adequate to understanding the changes affecting all of us", which entails the decolonisation of cultural practices. We must think globally and act locally, be aware of universal myths, while remaining aware of the local circumstances and myths that surround us. In other words, a fruitful dialectical relation can ensue. In Slovenia, scholars often complain that, aside from specialists, nobody is "internationally" interested in local myths or national topics. This is not true: what is necessary is to find an appropriate way to present local or national topics within an international and global setting. 